\title{
Antu Language in the Sangin Oral Narrative of the Sihans in Sarawak
}

\author{
*NORIAH MOHAMED ${ }^{1}$ \\ JAMILAH BEBE MOHAMAD ${ }^{2}$ \\ MOHD TARMIZI HASRAH ${ }^{3}$ \\ ${ }^{1}$ School of Humanities, Universiti Sains Malaysia, 11800 USM, Pulau Pinang, Malaysia \\ ${ }^{2}$ Department of Foreign Languages, Universiti Malaysia Pahang, Pahang, Malaysia \\ ${ }^{3}$ School of Languages, Civilisations and Philosophy, Universiti Utara Malaysia, Kedah, Malaysia \\ *Corresponding author: noreekeepli@yahoo.com
}

Published online: 31 May 2021

To cite this article: Noriah Mohamed, Jamilah Bebe Mohamad and Mohd Tarmizi Hasrah. 2021. Antu language in the sangin oral narrative of the Sihans in Sarawak. KEMANUSIAAN the Asian Journal of Humanities 28(1): 171-192. https://doi.org/10.21315/kajh2021.28.1.8

To link to this article: https://doi.org/10.21315/kajh2021.28.1.8

\begin{abstract}
This article discusses the Sihan community and one of their traditional oral narratives, known as sangin. Sihan is an indigenous ethnic group residing in Belaga, Sarawak, Malaysia, and sangin is an activity that can be considered a folklore, narrative in manner, and performed for entertainment and native remedy. Data on the community in this study was obtained through interviews with 71 Sihan informants in Belaga, Sarawak, Malaysia. The sangin by one of its practitioners was recorded during the community's leisure activities. The recorded sangin song, delivered in the style of storytelling, narrated for entertainment, not for remedy purposes. The description of the sangin indicates that the language in the oral tradition, called antu language (language of the spirit) is very different from the modern, every day Sihan language used by its speakers. In terms of usage, sangin can be considered extinct because of the reduced number of Sihan speakers (only 218 left) and lessening number of sangin practitioners (only three remain). Sangin as a native remedy no longer has a place in the community with the availability of modern medical treatment, the mass migration of the Sihans from their original area, and the change in the Sihans' life style, from nomadic to community life.
\end{abstract}

Keywords and phrases: Sihan, identity, native, sangin, antu language

\section{Introduction}

This article elaborates on the ethnography of the Sihan community, particularly their identity, and describes an oral tradition practiced in the community known as sangin. It is a practice of the Sihan community in Belaga, Sarawak, Malaysia. 
The community can be considered to be threatened because census shows that in 2015, there were only 218 of them. Due to this and a few other factors, their traditional activities are less practiced, including sangin. Sangin is a traditional oral narrative, sung for entertainment and medical purposes. This article elaborates on the ethnography of the Sihan community and its relation to sangin, focusing particularly on the difference between the language used in sangin, known as antu language (or language of the spirit) and the daily language currently used by the community.

\section{Who are the Sihans?}

Sihan or Sian is one of the indigenous communities found in the town of Belaga in the Seventh Division of Sarawak, Malaysia. Gordon's (2005) data in Table 1 shows that the total number of the Sihan people is 50 . This data can be used as a general guide $^{1}$ only. Field surveys however show that there are total of 218 speakers of Sihan. This means that the total number of native speakers are 218 and generally, their ratio to the entire population of Malaysia is approximately 0.0000109 .

Table 1. General information of Sihan

\begin{tabular}{ll}
\hline Ethnic & Information \\
\hline Sian & A language of Malaysia (Sarawak) ISO 639-3: spg. \\
& Population: 50 (2000 Wurm). \\
& Region: Belaga, 7th Division. \\
& Language map: Brunei and Malaysia - Sarawak, reference number 48. \\
& Alternate names: Sihan. \\
& Dialects: May be intelligible with Bukitan, Ukit, Punan Batu 1. \\
& Classification: Austronesian, Malayo-Polynesian, North Borneo, \\
& Melanau-Kajang, Kajang. \\
& Comments: Nearly extinct.
\end{tabular}

Source: Gordon (2005)

The UNESCO scale notes that the number of speakers alone is not enough to provide clear indications of the vulnerability of a community, "yet ceteris paribus, a smaller group is likely to be under greater pressure than a larger group" (Lewis $2005,12)$. This shows that native speakers of Sihan are indeed small in number and therefore threatened. As Brenzinger et al. $(2003,8)$ argue, "A small population is much more vulnerable to decimation (e.g. by disease, warfare, or natural disaster) than a larger one. A small language group may also merge with a neighbouring group, losing its own language and culture". 
Sihan is categorised as a group that belongs to the ethnic category called Kajang. Although the word Kajang has not been comprehensively discussed, Maxwell $(1992,5)$ states that Kajang refers to three aspects. First, Kajang means natives other than Kayan or those who are not Kayan. Secondly, Kajang means ethnic people who eat sago (pantu or mulung) (eaters of palm starch) and make this food as part of their traditional diet. Thirdly, Kajang means the place of origin of this group, which is in the Kajang River Valley. Kajang is a tributary of the Linau River which is originally located in the most remote area in the Seventh Division of Sarawak on the Indonesian border. These three aspects are used to group the Ukit, Sihan, Punan, Punan Usang, Punan Busang, Punan Peliran, Punan Sipeng, Punan Ulu Belaga, Punan Ulu Silat, Punan Bah, Baketan Sekapan, Kejaman, Lahanan, Lisum and Tanjong people below the Kajang ethnic category.

According to Sandin $(1985,70)$, the Sihan people are associated with the Penan or Punan group who stated "the Kayan called us (Sihan) Penan while we called ourselves Punan". Although they consider themselves Punan, not all Punan groups have anything to do with Sihan (Punan) people. In this regard, during an interview with Sandin, the Sihan people stated, "We speak the same language with Punan Bushang and Punan Aput, and not with other Punan. ${ }^{2}$ We consider that the Punan Tanah is 'ethnically' ours. We eat the same food and follow the same custom, though our language is not the same" (Sandin 1985, 70).

Nevertheless, the terms Punan and Penan are considered to be similar in general. Even the Sihan people agree that "there is no difference between the Punan and Penan" (Sandin 1985, 70). However, there are two different views in the discussion of Sihan.

Sihan is associated with Punan because allegedly they are actually Punan Batu people who once occupied Mujong, Baleh. In the settlement, the Sihan (Punan) people are called the "cavemen" because they are said to live in the cave of one of the hills, probably Bukit Batu. However, the modern Sihan people today claim that they do not know the story. The survey carried out in the current study also shows that people in Belaga do not know about the Punan Batu people. Nonetheless, some Sihan informants interviewed stated that they had heard of the said cavemen. The cavemen are considered dwarfs who were difficult to detect because they were very agile.

Gordon (2005), in Ethnologue: Languages of the World, lists the languages of Punan Batu 1 as in Table 2. 
Table 2. General information of Punan Batu 1

\begin{tabular}{ll}
\hline Language & Information \\
\hline Punan Batu 1 & [pnm] 30 (2000 Wurm). Central, west of Long Geng, southeast of Belaga. \\
& Classification: Austronesian, Malayo-Polynesian, Northwest, \\
& Melanau-Kajang, Kajang. \\
& Nearly extinct. \\
\hline
\end{tabular}

It may be true that the Sihan people are not Punan Batu people because earlier, Urquhart $(1955,193)$ who listed the dialects in Kapit area mentioned that among his informants was Nyupeh, son of Nyakin, who lived in Punan Batu houses but at the same time, he stated that he did not list the vocabulary of three languages, namely Chinese, Sian and Punan Busang. It is apparent that the language of Punan Batu spoken by this Punan Batu informant is not the Sihan language. Similarly, Maxwell $(1992,7)$ notes that "Sihan and Punan Batu share clear cognates for 48 items and have noncognate forms for 39 items" also clearly shows that Sihan language with Punan Batu language is not the same language but has kinship relationship at the language family level.

Secondly, there is a difference between the terms Punan and Penan. Aichner (1958, 742) records that "Some Punan Tana have lately settled down in long-houses and started farming e.g. in the Jelalong River. But they want to be called now Penan instead of Punan to show their changed status".

In other words, Sihan referred to themselves as Punan probably because they once practiced a nomadic lifestyle. According to Kelbling $(1983,149)$ the three groups, namely Penan Talun, Ukit and Sihan have no tradition of building longhouses because their nomadic lifestyle did not require it. When their nomadic life was abandoned, they built longhouses according to the style of their neighbours. Perhaps their previous nomadic life pattern caused the Sihan people to prefer to be called Punan, not Penan.

The term Orang Ulu has also been used to refer to the Sihan people. Although from an ethnic point of view it is not very accurate, this reference is appropriate if it is associated with the place where the community resided. This is supported by the Taman Budaya Rumah Orang Ulu record (as retrieved from http:// www.malaysiahotelreview.com/sarawak/destination/rumah-orang-ulu.shtml) which reads: 
The term Orang Ulu is not ethnically correct per se, mainly because it consists of various well-distinguished ethnic groups such as the Kayan, the Kenyah, the Kelabit (found in the famous Bario Highlands), the Lun Bawang and to a certain extent, the Penan. Nonetheless, the term Orang Ulu is associated with the tribes living in the inaccessible interior regions of Sarawak rainforests. In fact, orang (means "people") and ulu (means "interior or up-river regions") is often useful to signify the "up-river dwellers" who often settle in the middle and upper reaches of Sarawak's many great rivers.

In this case, although the Sihan people are not those who come from the upstream area, which is Belaga, further examination suggests that they are a group that migrated from their original settlement area in Mujong, Baleh then to Namang River and then to Belaga (as shown in Figure 1).

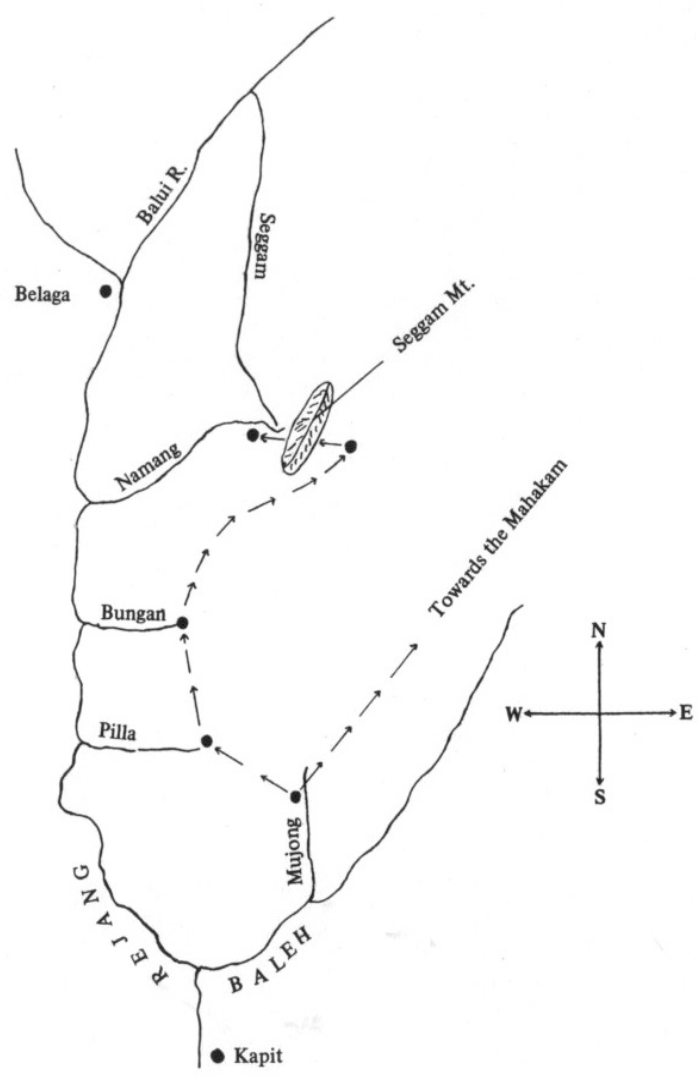

Figure 1. Migration of Sihan people from Rejang River to Balui River Source: Sandin $(1985,69)$ 
In fact, the movement of the Sihan people come about from downstream (Mujong, Baleh), upstream or north to Namang River and then to Belaga. That is why they are also classified as Orang Ulu.

It can be concluded that the Sihan people belong to the indigenous groups of Kajang, Punan or Penan and Orang Ulu in Sarawak. This group is rarely discussed because it is considered the same as other Punan or Penan people. Although the Sihan language is not the same as other Punan or Penan languages, except Punan Bushang and Punan Aput, it is often considered a dialect of the Punan or Penan languages.

From another perspective, since the Sihans are also a group that migrated from the Kajang Valley, they are also included under the Kajang ethnic category. After their migration from the downstream area, they settled in Belaga, which is one of the settlement area considered as the middle or upstream area. Hence, they are considered Orang Ulu.

The displacement of the Sihan people from their original area has forced them to change their original way of living ${ }^{3}$ to a new one. Among the most significant is that they no longer stay at longhouses but rent village houses surrounded by Malays and Chinese (Figures 2a and 2b). Although the Sihans still live in groups, some stay in individual homes.

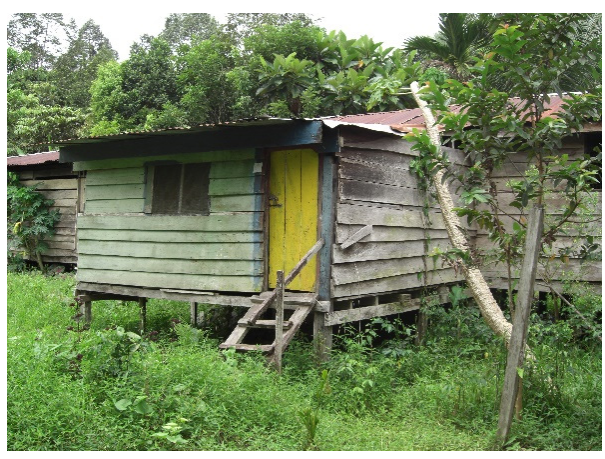

(a)

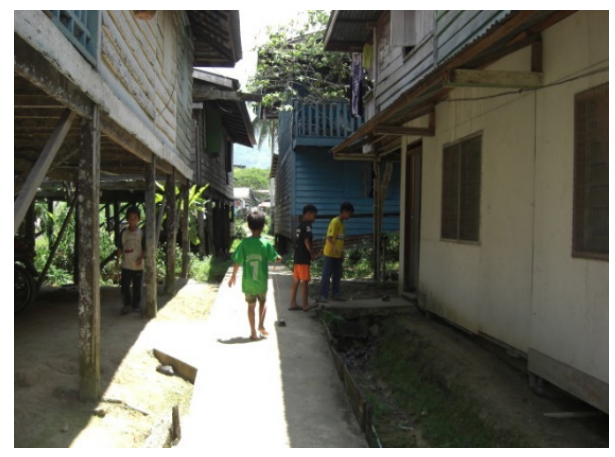

(b)

Figure 2. (a) Some longhouses in Sihan's original residence in Namang River and (b) Sihan's rental houses in their new settlements in the Malay Village, Belaga

They still plant upland rice although the upland is far away, approximately an hour ride by car or motorcycle. The original longhouses still remain. They return to the longhouses after harvesting to celebrate the end of the harvest season. 
The Sihan's traditional culture has also changed, modified or not practiced at all and replaced with a borrowed culture. According to Noriah and Muhammad Khairi (2011) and Noriah (2013), the decrease in traditional practices such as customs and traditional remedies indicates the decline of the use of the Sihan language in these domains. Table 3 shows the decline in customs and traditional remedy domains that use the Sihan language.

Table 3. Decrease in customs and traditional remedies domains using the Sihan language

\begin{tabular}{llcccccc}
\hline Language & $\begin{array}{l}\text { Scale/ } \\
\text { Domain }\end{array}$ & $\begin{array}{c}\mathbf{1} \\
\text { (Never) }\end{array}$ & $\begin{array}{c}\mathbf{2} \\
\text { (Seldom) }\end{array}$ & $\begin{array}{c}\mathbf{3} \\
\text { (Sometimes) }\end{array}$ & $\begin{array}{c}\mathbf{4} \\
\text { (Often) }\end{array}$ & $\begin{array}{c}\mathbf{5} \\
\text { (Always) }\end{array}$ \\
\hline Sihan & Customs & 24 & 6 & 8 & 6 & 27 & 71 \\
& & $33.8 \%$ & $8.5 \%$ & $11.3 \%$ & $8.5 \%$ & $38.0 \%$ & \\
& Traditional & 23 & 1 & 6 & 8 & 33 & 71 \\
& remedies & $32.4 \%$ & $1.4 \%$ & $8.5 \%$ & $11.3 \%$ & $46.5 \%$ & \\
\hline
\end{tabular}

Source: Noriah $(2013,7)$

In this context, the Sihan language is not only not used in this domain but in fact, their customs and traditional remedies are disappearing as their members embrace Christianity.

Before the arrival of Europeans in Sarawak, most indigenous groups practiced their own religion and beliefs. The practice of paganism or animism encouraged them to cling to supernatural powers and have great respect for natural elements such as forests, mountains, hills, rivers, animals and crops, and especially rice. However, most traditional practices that used their mother tongue, especially archaic ones such as witchcraft is no longer practiced in these communities. For example, the Majlis Berantu, ceremony for the Langgie Pingadap (appreciation dance to thank god) practiced by the Bidayuh people is shortened by removing certain parts of the ritual after the Bidayuhs converted to Christianity (Nais 1989).

Changes that the Sihan community is facing today is also gradually eroding old beliefs they held for so long. Based on the survey conducted, it was found that almost all members of this community had converted to Christianity (Catholic or the Borneo Evangelical Church) and their ancient customs are considered contrary to Christian teachings. Although the majority of the population still lives in the village and is involved in the agricultural sector, the younger generation in particular has gained exposure to education, because of government efforts. 
In this community, written materials related to their history or origin also do not exist. However, one of the informants of the current study stated that the Sihans have a type of oral folklore, a sing-song tradition known as sangin.

\section{Sangin as Literature and Folklore}

Sangin is sung by individuals who are half-drunk. The two basic purposes of sangin are as native remedy and entertainment. In terms of remedy, sangin is a spell (probably similar to manang among the Iban people) sung to cure diseases, and takes several hours. Unfortunately, when asked about the sangin witchcraft/shaman activity during the field study, most informants laughed it off because they believe the activity no longer goes with the times and their new religion, Christianity. However, at the time of the study, there was an individual, Mr. Meilee, in the community who is said to be able to hold a sangin witchcraft/ shaman ceremony for healing purposes.

In general, sangin can be considered as a folk literature, which refers to literature born in a given society. This is because it contains at least the following four things. First of all, a folk literature is usually delivered orally. This literature is presented individually to an individual or a group of other individuals. Secondly, this literature is dynamic in nature. Folk literature will often experience additional storytelling or reduction, depending on the situation and time. Thirdly, this literature is a public property. There is no issue of copyright or absolute ownership on a folk literature. Fourthly, this literature often has an element of rhythm. A folk literature delivered often contains elements of interesting rhythm. This arrangement is made so that the story is more entertaining to the listener as well as making it easier for the narrator to compose the story.

Usually, a folk literature refers to folk literature from the past that has been passed down to future generations. A folk literature is a part of the ancestor's culture. In the Sihan community, sangin is a folk literature that fulfils these four characteristics.

In particular, sangin is a folk literature in the category of folklore, which is a form of art or heritage of a society that is passed down orally from one generation to another. It is clear that sangin as an oral tradition that can also be classified as a folklore. Since this folklore is sung as a story, this activity can also be considered as a type of oral narrative. Sangin narrative folklore is sacred when the language used to convey it is the language of the spirit called the antu language by the Sihan people. Sangin can also be considered as a ritual language under behavioural folklore because this activity involves witchcraft rituals, which is a method in treating patients traditionally. 


\section{Sangin as a Ritual Language}

Language does not only involve grammar elements. It also contains outer element that is not outlined in the grammar structure. These elements are sometimes more important than grammar due to its closeness in connecting human with the world or surroundings. In other words, in a language, apart from the grammar, it also comprises social and cultural elements of the speaker. Therefore, observing language practices in the speakers' community makes us realise that human language is dynamic. The existence of these varieties underlines the fact that as a communication tool language should not be uniform, but should possess variety, complexity and diversity. One reflection of variety that is heavy with social and cultural nuances is the language of rituals.

The variety of ritual language received attention in Robert Blust's magnum opus, entitled The Austronesian Languages. He discusses ritual language traits in the chapter "Language in Society" (Blust 2009, 143-144). Ritual language is interesting, especially those found in Austronesian languages.

The discussion on ritual language should begin with definition of the concept of ritual language concept. What do we understand from a ritual language? It can be roughly defined as a variation or language variety with linguistic system and specific context use involving supremacy and spirit worshipping. In other word, it is a set of steadfast utterance and closely related in the foundation with certain ritual (Wheelock 1982). Additionally, ritual language is not only an instrument of notion realisation but it also involved to ensure the precision of a ceremony. Failure in uttering ritual language in a fluent manner will not lead to a success of a ceremony. In Malay culture, there are shaman practices that involve certain spells and incantation in calling the spirit. These elements are obeyed in terms of its articulation, word choices as well the arrangement in the utterances. Without this compliance, a shaman will fail in calling the spirit to be with him. Thus, ritual language is a specific variety among other language variants as it has its own nomenclature. This difference is clearly portrayed in the linguistic system and its uses.

\section{Linguistic System of the Ritual Language}

Linguistically, ritual language has a specific system. According to Fox (1971; 2005), the system is known as semantic parallelism. This concept however, is Fox's, but was first discovered in Hebrew tradition. The term is borrowed by Fox from the famous linguist, Roman Jakobson. What does semantic parallelism mean? 
To understand semantic parallelism context, we need to see the chants structure, spells, incantations and other related aspect pertaining to ritual language. The mentioned elements are formed in lines and they interact with each other to develop strong semantic parallelism. Therefore, at a glance, semantic parallelism is developed by a trait that ties each utterance (chants, spell, incantation and others) uttered by the mediator (shaman, sorcerer, witchdoctor and the experts in spiritual matters) of the language. Fox $(1971,230 ; 2005,143)$ outlines an easy example in understanding semantic parallelism. The following is the burial chants from the Roti language:

Table 4. Semantic parallelism in ritual language

\begin{tabular}{ll}
\hline Roti & English \\
\hline soku-la (a1) Pinga (b1) Pasa (c1) & They carry Pinga Pasa \\
(ma) ifa-la (a2) So'e (b2) Leli (c2) & (And) They lift So'e Leli \\
de ana sao (d1) Kolik (e1) Faenama (f1) & She marries Kolik Faenama \\
ma tu (d2) Bunak (e2) Tunulama (f2) & (and) weds Buna Tunulama \\
\hline
\end{tabular}

Based on the sample, semantic parallelism is present in connecting elements that are labelled a1//a2, b1//b2, c1//c2. ${ }^{4}$ In this element, verb form soku//ifa "carry and lift" and sao//tu "marry and wed" formed dyadic set, which are two different words as a reaction between one and another but carrying the same meaning.

What does dyadic set mean? Dyad refers to two persons; whereas dyadic is two persons interacting. By looking at the formal term of dyadic, the conceptual relationship with dyadic set applied by Fox is understood. In an event, ritual language normally involves utterance-response given by two persons, the shaman and his assistant. He will utter the first line and followed by the second line done by the assistant. The response in the second line is a response to the first line. They have different words being used but presented semantic parallelism. For instance, soku/lifa clearly shown the formation of semantic parallelism in ritual language.

According to Evans (1953), ritual language from a linguistic perspective can be elaborated based on five crucial elements. He discussed rinait, a sacred language used in a ritual by Dusun community in Sabah. The language which is also called bobolian, comprises five different forms: general words, special or poetic words, words that are not present in the daily use of the people but used in different village, loan words from Brunei Malay language and words used by bobolian in rinait. 
Prentice's (1981, 130-131) linguistic analysis of the ritual language of the Timogun Murut tribe in Sabah reports that there are at least five features contributing to the existence of words used in their ritual language. They are (1) conversion with synonymous words from ordinary language, (2) ritual word exists in Timogun language but with differences in meaning, (3) words of ritual language exist in everyday languages but in different forms (more derivative words than basic words), (4) many words of ritual language have cognates in other Murut languages, and (5) words of ritual language that do not have a direct connection with Timogun or other Murut languages.

The division by Prentice suggests the existence of a well-structured ritual language in the community. The structure is general and can be employed in analysing other ritual languages such as sangin.

\section{Use of Ritual Language}

The combination of "ritual" and "language" gives ritual languages a specific trait in terms of the context of its use. The term "ritual" carries the meaning of holy and sacred, usually related to the spiritual matter. Therefore, the use of this language is greater than everyday speech. In other words, this language is solely used by an individual with extensive knowledge on the matters with the connoted meanings. Other than that, the context of its use is very specific. According to Fox (1971, $220)$, in the Roti tribe, ritual language is used in the specific contexts such as funeral, farewell, seeking something from the ancestors and engagement.

\section{Literature Review}

Like other language families, ritual language in the Austronesian language family has also received research attention. According to Blust (2009, 143), when starting a discussion on ritual language, Fox may be one of the scholars who has done the most extensive research in this field. This is due to his success in identifying the characteristics of ritual language in the Austronesian language family through the concept of semantic parallelism aforementioned.

In a more recent study, Fox (2005) discussed the history of Austronesian language rituals studies, which include among others, the Iban ritual language known as basa sanggiang or spirit language, the Mualang Dayak and Kendayan ritual languages in West Borneo, the puyuma ritual language in Taiwan, the Nias tribe ritual language, the boolang mongondow ritual language in Philippines, the Toraja-Sa'dan ritual language, and atoni pah meto ritual language in West Timor. 
The studies applied ethnographic analysis as well as semantic analysis of each word used in ritual language practices. The study on basa sanggiang in Iban community in Borneo for instance shows that historically, basa sanggiang documentation existed since 1858 in Versuch einer Grammatik der Dajackschen Sprache by a Bible translator named A. Hardeland. The collection effort continued to intensify and the most basic outcome was by the Swiss evangelist H. Scharer (1963) with two volumes of the basa sanggiang texts. Several other researchers subsequently developed the basa sanggiang language corpus, among them was Sri Kuhnt-Saptodewo (1993; 1999). Despite its substantial documentation, all these works do not take advantage of the application of linguistic points of view in order to explain the basa sanggiang system. This may be due to the fact that the goal was only for documentation.

Perhaps Fox's studies of the Roti ritual language (1971; 1993) were among those that successfully placed ritual language in a system that possesses a character or specific characteristic, namely semantic parallelism built from the dyadic interaction set. By using the concept of semantic parallelism, Fox managed to present an intact system of ritual language. Although it is basically built from the Roti ritual language, this system is also able to explain the phenomena that exist in the basa sanggiang. This is because basa sanggiang in the Iban society also shows the same strategy and structure of ritual language. Semantic parallelism does not only exist in basa sanggiang but this parallelism may be universal in the Austronesian language families, which exists in the ritual language from Taiwan to Easter Island. In addition to the emphasis on systems and semantics, there are other forms of analysis in Fox study. One of them is tracing the origin of words.

As stated before, ritual language has specific words which are mostly very different from everyday language. The question is, where did the words come from? As mentioned earlier, Evans (1953) and Prentice (1981) each divide the origin of words in the ritual language studied into five categories. In line with Prentice, Fox also took a similar stance in his analysis (1993). In his study of the Termanu tribe in Roti Island mentioned earlier, Fox collected chants of certain ritual practices. The chant contains 5,000 lines. Based on the chant data, he also compiled a dictionary consisting of almost 1,000 dyadic sets as entries. His analysis of the dyadic sets found that there were too many, not only words which were not used in everyday language but also in any dialect in Roti Island. This means that the words used in the chants were so special that the words were not available in common language.

In addition to tracing the origin of words, ritual language scrutiny also involves the analysis of the nature of communication itself. One relevant study is by Janet Hoskins (1988). In this study, Hoskins analysed the communication 
of spirits practiced by the Kodi tribe living in East Nusa Tenggara, Indonesia. Hoskin separated communication between "external spirits" and "inner spirits". Interestingly, Hoskins identified some of the traits that should be present in such communication practices, namely (1) the exclusive use of double words in two couplets or lines, (2) takes place in an open forum (one cannot speak to the spirit alone), (3) the use of metaphors loaded with nuances of respect, (4) must recognise the top hierarchy of the spirits, and this must be done through intermediaries, (5) diligent submission and (6) consensual accountability.

\section{Sangin as a Storytelling during Leisure}

In terms of structure, sangin is embedded discourse that has a specific theme or story. The stories told often revolve around people, including stories of gods, heroism, grief, travel, romance and others.

Usually, the mediator will drink tuak (liquor made from rice) to get into the best mood to tell the story. It has been suggested that, in a state of semi-intoxication, the mediator can convey the sangin better and more effectively. Usually, sangin is delivered solo, without musical accompaniment, and until the story ends. The mediator will continue to deliver the sangin as long as the effects of intoxication due to drinking tuak is still affecting him or her.

There are two main functions of sangin in the Sihan community, namely for entertainment and medical purposes (native remedy). Despite being sung as a leisure activity in the community, sangin is sung to welcome and celebrate the arrival of guests. In shaman activities, sangin is sung as a mantra to cure certain diseases, especially diseases that are believed to be caused by supernatural powers. The song also serves as a prayer to ward off evil and disease. In addition, sangin is also used to pray for the well-being of the community.

From a medical angle, sangin can be associated with rinait which is sung by bobolian among the Kadazan-Dusun people, alude singing practiced in Masingi and Maranata villages in Central Sulawesi, Indonesia and tombilo song which said to come from elves or goblins. Superficially, only certain individuals, considered chosen, can control these types of chanting, including the sangin. Those who have the ability to convey the sangin obtained it through dreams and the revealed verses did not come from the mediator but produced through the influence of a good deity. So sangin is not used by the Sihan community in their daily language. It uses a variation of the Sihan language called antu (spirit language) and this variation cannot be spoken or understood by ordinary people. To understand the meaning, the mediator or shaman will translate the meaning to the listener (if necessary). 
The use of sangin in native remedy activity leads to ritual language. As stated earlier, ritual language carries the connotations of hallowed, holy, sacred and related to supernatural things. Therefore, its use is also not as arbitrary as daily spoken language. According to the informant, if sangin was used in the healing context, it is actually a prayer to the gods who use shaman as intermediary by using variations of language understood by them. This can be associated with an incantation or mantra used by the shaman to invoke the help of spirits during the medication ceremony among the Malays.

The use of sangin as a ritual language is not only on the verge of extinction but may be said to be extinct. Besides the declining number of the Sihans, their relocation to more modern areas and conversion to Christianity have caused the pagan elements to be seen as nonsense and forbidden in practice.

Mr. Meilee is the only shaman left among the Sihan people. He rarely performed the healing ceremonies due to his old age, and during the field study of the current research, he was ill.

One of the reasons sangin healing among the Sihan is extinct is because there is no formal institution that teaches sangin to the younger generation. ${ }^{5}$ This may be due to the fact that the members of the Sihan community are small. This cultural tradition is not accepted by Sihans who are Christians as the pagan ritual is not in line with Christianity. The language of sangin, which is unlike the modern Sihan language, also affects the younger generation negatively. This also occurs among the Melanau people (in Mukah, Oya, Dalat and elsewhere in Sarawak) who use the archaic Melanau language in the kaul (sea worship tradition). Modern Melanau speakers find it difficult to understand the language of incantations used to summon ipok-ipok (sea goddess); the song worship ipok-ipok as they (the speakers) ride the tibow (cradle) or the pantun (pantoum) to ensure the tibow is secure. The disinterest among the younger generation is possibly due to the use of obsolete terms and archaic vocabulary (Pan, Chong and Remy 2017, 35). Moreover, ritual language structure that is allegorical in nature (e.g. language in the ritual of sugi sakit among the Iban) that requires proper elocution and repetition (Sather 2016) does not interest speakers from the younger generation.

Thus, sangin is practiced for leisure in the evening or at night when the Sihans returned from the field. Sangin for entertainment however is not the same as native remedy. Many aspects of the original ritual language have been diluted. Two middle-aged women learned to sing the sangin from Mr. Meilee. They memorised the verses of the story in sangin, which are said to be different from the variations of the Sihan language used today. Nevertheless, sangin is not a sacred language 
that is static in nature which simply can be memorised and represented. In sangin medical context, the singer is considered to have magical abilities that can enter the spirit world, get into a trance and can cure patients. The extraordinary ability of the sangin singer for entertainment purposes is choosing diction, morphology and syntax from a language that is not their daily spoken language to produce impromptu sangin verses.

They need to memorise verses from a language called antu or spirit language. The memorisation should also be accompanied by an understanding of the meaning of each selected lexical because among the common Sihan people, this variation of language is not understood if they do not learn it. Sangin singer needs to translate the antu language if requested by his audience.

\section{Sangin in Spirit Language}

The following is one of the stories told through sangin during a leisure activity in one of the community rental houses. The audience or interlocutors in the context of this presentation consist of children, younger generation and older generation of this community. Note the difference between antu language, the spirit language/ secret language, and the Sihan language.

Table 5. Antu language in sangin

\begin{tabular}{lll}
\hline $\begin{array}{l}\text { Antu language } \\
\text { Diho molo akou }\end{array}$ & Sihan language & $\begin{array}{l}\text { Malay language } \\
\text { (translation in English) }\end{array}$ \\
tiring & Ditto mengayau & $\begin{array}{l}\text { Marilah memotong kepala } \\
\text { (let's behead) }\end{array}$ \\
nyang & polo & $\begin{array}{l}\text { naiklah perahu } \\
\text { (get in the canoe) } \\
\text { dayung } \\
\text { (row) }\end{array}$ \\
garing tirang tet linga & ngapo alui tok linga & $\begin{array}{l}\text { singgahlah perahu di batu } \\
\text { (stop the canoe at the rock) }\end{array}$ \\
garing kohen lemajeyo & afvan lafvik hen lajey lafunk & $\begin{array}{l}\text { datanglah dia ke rumahmu } \\
\text { (he comes to your house) }\end{array}$ \\
Hen menyelan barak tavey & Hen alak klovi oro & $\begin{array}{l}\text { Dia mengambil seorang } \\
\text { anak dara } \\
\text { (he takes a virgin) }\end{array}$ \\
& hai kom bowong cangam & $\begin{array}{l}\text { marilah orang bujang yang } \\
\text { kuat } \\
\text { (come the strong bachelor) }\end{array}$ \\
\hline
\end{tabular}


Table 1. (continued)

\begin{tabular}{|c|c|c|}
\hline Antu language & Sihan language & $\begin{array}{l}\text { Malay language } \\
\text { (translation in English) }\end{array}$ \\
\hline $\begin{array}{l}\text { garing kohen nakarin } \\
\text { tet linga litak }\end{array}$ & $\begin{array}{l}\text { guap kohen kat diva amai } \\
\text { linga temo dovo papet }\end{array}$ & $\begin{array}{l}\text { terus mereka berlawan } \\
\text { dengan parang } \\
\text { (they fight with machetes) }\end{array}$ \\
\hline o'go jajat & hen nyajat malat & $\begin{array}{l}\text { dia menarik parang } \\
\text { (he pulls the machete) }\end{array}$ \\
\hline punang kango & punang ulun & $\begin{array}{l}\text { potong kepala } \\
\text { (behead) }\end{array}$ \\
\hline abbey ko to pelito & to wey co to miyum & $\begin{array}{l}\text { marilah minum } \\
\text { (come drink) }\end{array}$ \\
\hline lolon man ling & batang lokok & $\begin{array}{l}\text { sebatang rokok } \\
\text { (a cigarette) }\end{array}$ \\
\hline annei kou ne sinup man ling & cip nuk batang lokok & $\begin{array}{l}\text { hisaplah sebatang rokok } \\
\text { (smoke a cigarette) }\end{array}$ \\
\hline ni lulun ayop & ini cipak nuk & $\begin{array}{l}\text { ini sirih kamu } \\
\text { (here's your beetle leaf) }\end{array}$ \\
\hline nyalitan ngenou litak & yajat mey oyat & $\begin{array}{l}\text { marilah kita menari } \\
\text { (let us dance) }\end{array}$ \\
\hline annei nge sinup jakan & tuweykou lok miyup burak & $\begin{array}{l}\text { marilah minum tuak } \\
\text { (let's drink tuak) }\end{array}$ \\
\hline pulang tovi & ulek to lok & $\begin{array}{l}\text { marilah pulang } \\
\text { (let's go home) }\end{array}$ \\
\hline Nyalitan ngenou litak & Yajat mey oyat & $\begin{array}{l}\text { Marilah kita menari } \\
\text { (let us dance) }\end{array}$ \\
\hline diho molo akou & ditto mengayau & $\begin{array}{l}\text { marilah memotong kepala } \\
\text { (let's behead) }\end{array}$ \\
\hline
\end{tabular}

This story is an excerpt from a larger discourse that revolves around the custom of beheading in Sihan society in the past. The story begins with a young man from a village who wants to gain strength by beheading. According to the story of the Sihan community, once upon a time, beheading is a custom that was practiced in the community when they were nomadic. In the story, the young man paddles a canoe towards a village. Upon arrival, the young man anchored his boat on a large rock. Later, the young man kidnapped a girl from a house in the village. The young man tried to lift the girl. According to the custom, if the young man can lift the girl then his combat strength is strong enough to fight with the village's youths but if otherwise, then the young man is not a champion and will not be able to fight with others. After the young man managed to lift the girl, then the young man was confident that his strength could overcome the youths of the village. 
The young man called on all the youths of the village to fight with him. So, a young man from the village responded to the young man's challenge to fight. They fought with machete. After fighting for so long, the young man who came from another village managed to cut off the head of the village's youth. After that, the young man brought his victim's head to his village to be presented to his people to lift him as a hero.

This is a brief synopsis of one of the sangins presented by one of the informants, Mrs. Konek. This recording was made while the mediator was semi-intoxicated. So, the translation of the text was re-confirmed by the mediator when she was sober.

The sangin presentation shows that the language used for entertainment is still the variation of Sihan language called the original antu language. As stated, this language variation is learned as a person learns other variations, dialects or languages. The antu vocabulary does not seem to be related to contemporary the Sihan language. The two vocabularies do not seem to resemble each other, as shown in Table 6.

Table 6. Unrelated sangin vocabulary to modern Sihan or other Austronesian languages

\begin{tabular}{lll}
\hline Sangin vocabulary & Modern Sihan vocabulary & Meaning in Malay \\
\hline Pelito/Sinup & Miyum/Miyup & Minum (drink) \\
Man ling & Lokok & Rokok (cigarette) \\
Kango & Ulun & Kepala (head) \\
\hline
\end{tabular}

Clearly, words used in sangin are very different from those in the Sihan language. The words may be a form that is still preserved or maintained in its original form while the Sihan language is an innovative form influenced by other languages. In relation to this, two of the Sihan words in Table 6 seem similar to Malay, which suggests that they are borrowed from the Malay language.

Variations of antu language in sangin also contain cognates. Cognates are words that are similar or almost the same, considered to be inherited from the same proto-language. Cognates in antu language are similar or alike to modern Sihan language or Austronesian language. Examples of cognates in the previous verse are as shown in Table 7: 
Table 7. List of cognates in sangin

\begin{tabular}{lll}
\hline Sangin vocabulary & Sihan vocabulary & Meaning in Malay \\
\hline Abbey ko to & To wey co to & Marilah (come/lets) \\
$\mathrm{Ni}$ & Ini & Ini (this) \\
Tet linga & Tok linga & Di batu (at the rock) \\
Hen & Hen & Dia (he) \\
Hai kom & Hai kom & Marilah (come/lets) \\
Bowong & Bowong & Orang bujang (bachelor) \\
Kohen & Kohen & Mereka (they) \\
Jajat & Nyajat & Menari (they) \\
Punang & Punang & Potong (cut) \\
\hline
\end{tabular}

Words such as taving which means "strong" in antu language still exist in modern Sihan language with the same meaning but used in different situations. For example, the proper name of the son of Sihan longhouse leader in Belaga is Taving anak Mergui. The words ni, pulang and ulek equate Malay words ini, pulang and balik. Ulun, on the other hand, is a cognate of $u l u$ which means "head" in royal variation of modern Malay. Yajat or ngajat which means dancing, and mengayau (beheading) in contemporary Sihan language have the same meaning in the Iban language.

The similarities comply the two final features of ritual language proposed by Prentice (1981) stated earlier. First, words in the ritual language do not have direct relation to the Sihan language or other Austronesian languages. Second, some words in the ritual language are cognates with the Sihan language or other Austronesian languages.

The antu language therefore may be a form of older language than the modern Sihan language. Both languages evolved from the same proto-language and during the evolution, changes in shape and meanings took place. The first correspondence shows the retention (which endures) of shape and meaning when the modern Sihan language develops from that early form. The second similarity shows that the antu language might be a form of older language than contemporay Sihan and its vocabularies consist of obsolete words not found in the Sihan language. The Sihan language has evolved over time and influences by other languages, especially the Malay language.

Although the examples of the antu language in this study do not show semantic parallelism and dyadic form, the discourse is intact, consisting of introduction, 
content and conclusion. The coherence aspect of the discourse is evident from the narration of the story. Documentation of other sangin may be able to provide further prove that this ritual language contains a language system with the structure that can be systematically described.

In terms of use, it may concluded that sangin as an entertainment still exists but rituals that carry connotations of pure, holy, sacred and supernatural powers are not evident. The original context of the ritual language involving unseen elements as audiences is not available in this type of sangin. The interlocutor is merely a presenter and listener. Sangin song is almost akin to the daily spoken language. The mediator is not a person with sufficient knowledge on matters with connoted meaning. In other words, the sangin system needs to be learned or memorised to be delivered orally.

\section{Conclusion}

Sangin, a form of folk tradition delivered in songlike manner, has existed in Sihan community for ages. However, the number of its practitioners is negligible and sangin is no longer used as source of entertainment. As a form of native remedy, sangin is no longer required given the migration of the Sihan people to town such as Belaga where modern medical facilities are available. The current study found the sangin can only be delivered by three individuals, who are all elderly. The eldest of them is the only one can use sangin as a native remedy to help cure the sick. Given this, sangin, may be extinct, unless something is done to preserve this traditional oral narrative.

\section{Acknowledgements}

This study is part of the research under the niche group "Sacred Heritage in the Archipelago" conducted for the School of Humanities, Universiti Sains Malaysia, Pulau Pinang, Malaysia.

\section{Notes}

1. The number of speakers is very difficult to determine because different sources used different criteria to collect the data. In addition to the census based on the views of SIL (Summer Institute of Linguistics) (Gordon 2005) used in this writing and the census data of the Malaysian government which recorded this figure based on ethnic groups, the researchers visited the Sihans longhouses to interview and record information from the speakers. 
2. Other Punan meant are Punan Losong, Punan Apan, Punan Silat, Punan Gang, Punan Suai, Punan Jelalong, Punan Serungo, Punan Nyirong and Punan Niah.

3. Maxwell (1992, 1-2) under the heading "Life at Rumah Sihan" tells about the life of the Sihan people in their longhouses in Menamang River.

4. Symbol use "//" a convention that refers to dyadic set.

5. For example, among the Kadazan-dusun people, there is a special institution to train bobolian (people who are good at reading rinait) using a special rinait teaching module) (Evans 1953).

\section{Bibliography}

Aichner, F.P. 1958. Punan, Penan, Bukitan, Kajaman, Kajang and Kayan. The Sarawak Museum Journal VIII: 12/27(Disember): 740-742.

Asiatour.com. n.d. Retrieved from http://www.asiatour.com/malaysia/e-11sara/em-sar10 .htm (accessed 26 March 2012).

Asmah Haji Omar. 1994. Bahasa-bahasa bumiputera di Sarawak. The Sarawak Museum Journal. XLVII: 68(December): 145-158.

1982. Language and society in Malaysia. Kuala Lumpur: Dewan Bahasa dan Pustaka.

Blust, R. 2009. The Austronesian languages. Canberra, Australia: Pacific Linguistics.

Brenzinger, M., Yamamoto, A., Aikawa, N., Koundiouba, D., Minasyan, A., Dwyer, A., Grinevald, C., Krauss, M., Miyaoka, O., Sakiyama, O., Smeets, R. and Zepeda, O. 2003. Language vitality and endangerment. Paris: UNESCO Expert Meeting on Safeguarding Endangered Languages.

Evans, I.H.N. 1953. The religion of the Tempasuk Dusuns of North Borneo. Cambridge: Cambridge University Press.

Fox, J.J., ed. 1988. To speak in pairs: Essays on the ritual languages of Eastern Indonesia. Cambridge: Cambridge University Press. https://doi.org/10.1017/CBO 9780511551369

2005. Ritual languages, special registers and speech decorum in Austronesian languages. In The Austronesian languages of Asia and Madagascar, eds. K.A. Adelaar and N. Himmelmann. London: Routledge.

1993. The dictionary of Rotinese formal dyadic language, revised with English to Rotinese glosses. Unpublished MSc diss., Australian National University.

1971. Semantic parallelism in Rotinese ritual languages. Bijdragen tot de taal-, land- en Volkenkunde 127(2): 215-255. https://doi.org/10.1163/22134379 $-90002782$

Gordon, R.G.J., ed. 2005. Ethnologue: Languages of the world, fifteenth edition. Dallas, TX: SIL International.

Hoskins, J.A. 1988. Etiquette in Kodi spirit communication: The lips told to pronounce, the mouths told to speak. In To speak in pairs: Essays on the ritual languages of Eastern Indonesia, ed. J.J. Fox, 29-63. Cambridge: Cambridge University Press. https://doi.org/10.1017/CBO9780511551369.002 
Jemut Masing. 1997. The coming of the gods: An Iban invocatory chant (Timang Gawai Amat) of the Baleh region, Sarawak. Canberra, Australia: Research School of Pacific and Asian Studies.

Kelbling, S. 1983. Longhouses at the Baluy River. The Sarawak Museum Journal XXXII: 53(August): 133-157.

Lewis, M.P. 2005. Towards categorisation of endangerment of the world's languages. In SIL electronic working papers SILEWP 2006-002. Retrieved from http://www .sil.org/silewp/abstract.asp?fef=2006-002 (accessed 20 March 2016).

Maxwell, A.R. 1992. Balui reconnaissances: The Sihan of Menamang River. The Sarawak Museum Journal XLIII: 64(December): 1-46.

Nais, W. 1989. Overview of Bidayuh culture. Sarawak Museum Journal 40(61) Part 2: 367-374.

Noriah Mohamed. 2013. Daya hidup bahasa Sihan. Paper presented at the Persidangan Antarabangsa Daya Hidup Bahasa dan Budaya. Petaling Jaya, Selangor, Malaysia, 5-6 June.

Noriah Mohamed and Muhammad Khairi Mohd Nor. 2011. Sangin dalam komuniti Sihan di Belaga, Sarawak. Paper presented at the ASEAN Folklore Seminar. Universiti Sains Malaysia, Pulau Pinang, Malaysia, 2-3 November.

Noriah Mohamed and Nor Hashimah Hashim. 2008. Language policy, language planning and the use of non-dominant language in Malaysia: Sihan versus Standard Malay. Paper presented at the Second International Conference on Language Development, Language Revitalization and Multilingual Education in Ethnolinguistic Communities. Bangkok, Thailand, 1-3 July.

Noriah Mohamed and Rohani Mohd Yusof. 2004. Pengelompokan leksikostatistik bahasa-bahasa bumiputera di Sarawak. Unpublished report, Universiti Sains Malaysia.

Noriah Mohamed, Muhammad Khairi Mohamed Nor and Nor Hashimah Hashim. 2009. Komuniti peribumi Sihan di Sarawak: Satu pengenalan ringkas. Paper presented at the Seminar Indegenous Pedagogi 2009. Kuala Lipis, Pahang, Malaysia, 12-13 October.

Noriah Mohamed, Nor Hashimah Hashim and Yahya Che Lah. 2009. Factors that influence the sustainability usage of three endangered indigenous languages in Malaysia. The International Journal of the Humanities 7(6): 169-192. https://doi.org/10.18848/1447-9508/CGP/v07i06/42691

Pan Hui, Chong Sin and Remy Gedat. 2017. Menyoroti dua tradisi pemujaan laut di Sarawak: Semah dan Kaul. International Journal of the Malay World and Civilisation (Iman) 5(1): 29-36.

Prentice, D.J. 1981. The Mistrel-priestess: A Timogun Murut exorcism ceremony and its liturgy. In Papers on Indonesian languages and literatures, eds. N. Philips and Khaidir Anwar. London: University of London.

Sandin, B. 1985. Notes on the Sian (Sihan) of Belaga. The Sarawak Museum Journal XXXIV: 55(December): 67-76.

Sandin, B. 1977. Gawai Burong: The chants and celebrations of the Iban Bird Festival. Edited with an introduction by C.A. Sather. Pulau Pinang, Malaysia: Universiti Sains Malaysia. 
Sather, C.A. 2016. The Sugi Sakit: Ritual storytelling in a Saribas rite of healing. Wacana 17(2): 251-277. https://doi.org/10.17510/wacana.v17i2.442

2001. Seeds of play, words of power: An ethnographic study of Iban shamanic chants. Sarawak, Malaysia: Tun Jugah Foundation jointly with the Borneo Research Council.

Scharer, H. 1963. Ngaju religion: The conception of god among a South Borneo people. Translated by R. Needham. The Hague: Nijhoff. https://doi.org/10.1007/978-94 -011-9346-7

Sri Kuhnt-Saptodewo, J. 1999. A bridge to the upper world: Sacred language of the Ngaju. Borneo Research Bulletin 30: 13-27.

1993. Zum seelengeleit bei den Ngaju am kahayan. Auswertung eines sakratextes zur manarung-zeremonie beim totenfest. Munchen, Germany: Akademischer Verlag.

Taman Budaya Rumah Orang Ulu. n.d. Retrieved from http://www.malaysiahotelreview. $\mathrm{com} /$ sarawak/destination/rumah-orang-ulu.shtml.

Urquhart, I.A.N. 1955. Some interior dialects. The Sarawak Museum Journal VI: 5/20(July): 193-204.

Wheelock, W.T. 1982. The problem of ritual language: From information to situation. Journal of the American Academy of Religion L(1): 49-72. https://doi.org/10.1093/ jaarel/L.1.49 